\title{
Stegomyia indices of Aedes aquatic stages in El Geneina town, Western Sudan
}

Hamid Hamid,,${ }^{1,2}$ Hiba Musa, ${ }^{1}$ Adla Ahmed, ${ }^{2}$ Tayseer Abdul Azeez, ${ }^{2}$ Asma Adam, ${ }^{2}$ Mwahib Abdel Malik, ${ }^{2}$ Azeeza El Tahir, ${ }^{2}$ Hmooda Kafy ${ }^{3}$ and Rasha Azrag ${ }^{4}$

${ }^{1}$ Health \& Nutrition Program, Catholic Relief Services Organization, West Darfur State, Sudan. ${ }^{2}$ Integrated Vector Management Unit, Ministry of Health, West Darfur State, Sudan. ${ }^{3}$ Directorate General of Primary Health Care, Federal Ministry of Health, Sudan. ${ }^{4}$ Vector Genetics and Control Laboratory, Department of Zoology, Faculty of Science, University of Khartoum, Sudan (Correspondence to: Rasha Azrag: razrag@hotmail.com).

\begin{abstract}
Background: Darfur in Western Sudan has the most volatile camps of internally displaced persons (IDPs) and has experienced several outbreaks of dengue, chikungunya and yellow fever.

Aims: To determine the prevalence and Stegomyia indices of Aedes aquatic stages in El Geneina town, Western Darfur.

Methods: Cross-sectional entomological surveys of immature stages of Aedes were carried out during August-November 2019 in 4 sites with IDP camps and a residential area with no camp.

Results: We searched 17730 houses, IDP camps and buildings of governmental corporations for Aedes larvae, and 6809 (38.4\%) were positive for Aedes aquatic stages. Both Aedes aegypti and Aedes vittatus larvae were found. However, Ae. aegypti constituted $>90 \%$ of the larvae. Six positive water containers were recorded: tyres, clay pots, barrels, plastic water tanks, flower vases and old cars: $26 \%$ of 92 tyres contained Aedes larvae compared to $23.8 \%$ of 21 old cars and $17.1 \%$ of 44198 clay pots. This suggested that clay pots were the main source of Aedes. The results showed high infestation of El Geneina town with Aedes immature stages in all study sites including public buildings and residential areas with no IDP camps. Stegomyia indices varied among study sites, and were more elevated in sites with IDP camps. For all sites, House index $=38.40$, Container Index $=11.40$, Breateu index $=13.60$ and Pupa Index $=27$.

Conclusion: Multisectoral response coupled with community participation are urgently needed to reduce the burden of Aedes-borne diseases in the unstable El Geneina town.

Citation: Hamid H; Musa H; Ahmed A; Abdul Azeez T; Adam A; Mwahib Abubaker Abdel Malik M; et al. Stegomyia indices of Aedes aquatic stages in El Geneina town, Western Sudan. East Mediterr Health J. 2021;27(12):1189-1196. https://doi.org/10.26719/emhj.21.073

Received: 23/02/21; accepted: 14/10/21

Copyright $@$ C World Health Organization (WHO) 2021. Open Access. Some rights reserved. This work is available under the CC BY-NC-SA 3.0 IGO license (https://creativecommons.org/licenses/by-nc-sa/3.o/igo)
\end{abstract}

\section{Introduction}

Greater Darfur, Western Sudan, has a history of yellow fever (YF) epidemics and has experienced several outbreaks of dengue fever (DF), dengue haemorrhagic fever (DHF), and West Nile virus (WNV) and chikungunya virus diseases $(1-5)$. Out of the 5 Darfur states, West Darfur was the most affected with high morbidity and mortality rates of DF, WNV and chikungunya virus (3). In August 2019-March 2020 West Darfur State Ministry of Health reported 135 positive cases of DF and 247 positive cases of chikungunya from 5 localities including the capital, El Geneina town (State Ministry of Health, unpublished data, 2020).

West Darfur suffered from civil war unrest due to intercommunal violence. Since 2003, internally displaced persons (IDPs) began flooding into El Geneina town from surrounding areas, which, like much of West Darfur, were greatly affected by militia activity. El Geneina town includes the most vulnerable IDP camps in Sudan as a result of intercommunal violence, which has doubled in the second half of 2020. One of the important results of intercommunal violence that characterize IDPs in El Geneina town is that when attacks happen, IDPs fled and found temporary refuge in public buildings located within the town or escaped to Chad. There is continuous movement of inhabitants between El Geneina and Adri in Chad for purposes of marketing, seeking healthcare services and escaping intercommunal violence in IDP camps. This movement raises special concern about the transmission of Aedes-borne diseases across the countries' borders.

Despite the fact that Aedes-borne diseases are reported in Elgenina town, there is a lack of published data concerning Stegomyia indices of Aedes mosquitoes. The present study aimed to determine the prevalence and Stegomyia indices of Aedes aquatic stages in El Geneina town during an outbreak of DF and chikungunya.

\section{Methods}

\section{Study area}

West Darfur State is in the western part of Sudan between $11-15 \mathrm{~N}$ and $22-25 \mathrm{E}$. West Darfur is the least populated state in Darfur, with about $41 \%$ of the population residing in IDP camps and hard-to-reach areas. It is located across 2 different climatic zones, savannah with relatively high rainfall in the south and the semi-desert in the north. The state is mainly flat but interrupted in 
some areas with small hills and seasonal valleys. The prevailing climate is tropical continental, with temperatures ranging between 10 and $40^{\circ} \mathrm{C}$, with a mean monthly temperature of around $35^{\circ} \mathrm{C}$. El Geneina town is located in the savannah zone with relatively high rainfall. It lies at an open border with Adri town, Chad (distance $<30 \mathrm{~km}$ ).

\section{Study sites}

Entomological surveys were conducted in 4 residential areas with IDP camps: Omdoin, Ardamata, Elgabal and Almadaris (including both Madinat Elhujjaj and Riad IDP camps), in addition to a residential area with no IDPs, El shati in El Geneina town (Figure 1). Each site was divided into 2 groups: households, and IDP camps and public buildings. For surveying purposes, households and IDP camps were grouped together as significant numbers of IDPs live near residences. Public buildings included buildings of governmental corporations, organizations, health facilities, guest houses, tea shops, restaurants, grain mills and garages. Public buildings have different infrastructure which could further affect types, number, volume and usage of water containers; therefore, they were treated as a separate group.

\section{Entomological surveys}

Entomological surveys were carried out during August-November 2019. Entomological surveillance data were collected on a daily basis during the study period from all target premises and corporations in the 5 study sites. Data were recorded in a standard modified World Health Organization form. Each team comprised 2 health workers and a supervisor; 1 health worker conducted the inspection and the other led discussion with household members and distributed information, education and communication materials. Each team visited 20 houses per day. Larvae and pupae from water containers were counted and recorded. All positive water containers were emptied and internal surfaces of water containers were cleaned (source reduction) in the presence of the household head and members, supervisors in public buildings and the sheikh (local leader) in IDP camps.

\section{Morphological identification of Aedes larvae}

A random sample of Aedes larvae from each site was preserved in $80 \%$ ethanol for further morphological identification. No morphological identification was carried out on pupal stages. Samples of Aedes larvae were morphologically identified using the identification key in Sudan (6).

\section{Calculation of Stegomyia indices}

Stegomyia indices were calculated using Microsoft Excel. Aedes indices were calculated using the following formulae $(7,8)$ :

House Index $(\mathrm{HI})=$ Number of positive houses for Aedes larvae and pupae/Number of inspected houses $\times 100$

Container Index $(\mathrm{CI})=$ Number of positive containers with Aedes larvae and pupae/Number of containers inspected $\times 100$

Breteau Index $(\mathrm{BI})=$ Number of positive containers with larvae and pupae/Total number of houses inspected per 100 houses.

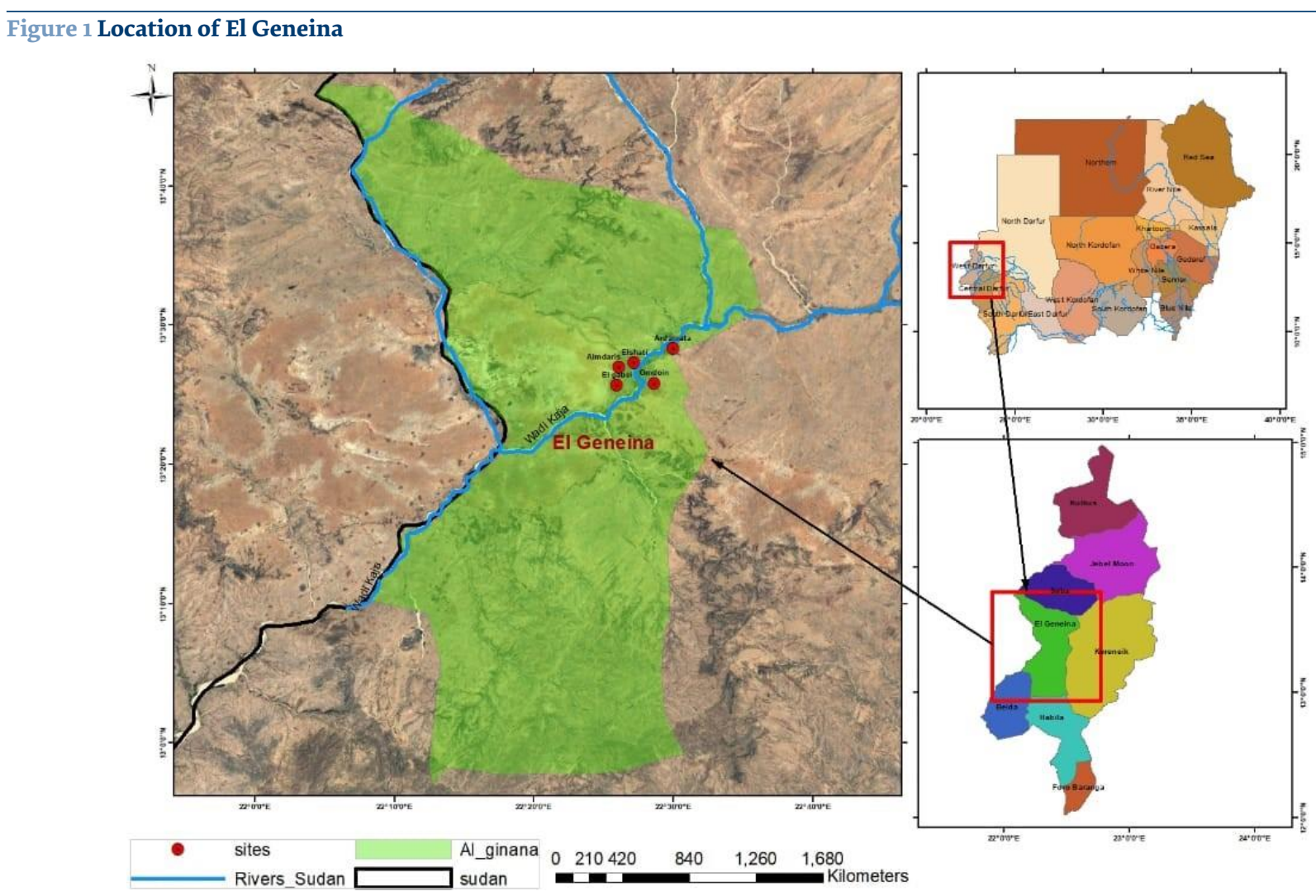


Pupa Index (PI): Total number of collected pupae of Aedes mosquitoes/Total number of inhabitants in the inspected houses per 100 houses.

Productivity of pupae $/$ larvae $=$ Total number of pupae $/$ larvae in specific container or cluster/Total number of pupae/larvae in all containers or clusters.

\section{Results}

\section{Identification and prevalence of Aedes mosquitoes}

Morphological identification of Aedes samples showed the presence of 2 species, Ae. aegypti and Ae. vittatus. Ae. aegypti represented $>90.0 \%$ of collected larvae and was recorded in all surveyed clusters, whereas Ae. vittatus was recorded in Omdoin households and IDP camps in both zeers and water tanks.

Six types of water containers were recorded, which included tyres, clay pots (locally known as zeers and used to preserve drinking water), barrels, plastic water tanks, flower vases and old cars (Table 1). Aedes immature stages were more abundant in tyres $(26 \%)$ and old cars $(23.8 \%)$ compared to zeers (17.1\%). However, tyres and old cars might not represent the main source of Aedes mosquitoes due to their low numbers (92 and 21, respectively) compared to zeers (44 198). Flower vases recorded low positivity rates in comparison to water tanks used for preserving water for different household activities such as cooking and washing clothes.

A total of 17730 households, IDP camps and public buildings were searched for Aedes immature stages, and 6809 (38.4\%) were positive. The results showed the high infestation of El Geneina town with Aedes immature stages in all study sites including public buildings and residential areas with no IDP camps.

\section{Stegomyia indices}

Stegomyia indices varied among study sites, and were more elevated in sites with IDP camps compared to those without IDP camps (Table 2). HI and CI were higher in households and IDP camps in Omdoin and Ardamata in comparison with other sites with IDP camps and El shati residential area with no IDP camp. However, public buildings in Elgabal site had the highest HI, CI and BI in comparison with other public buildings in the area. BI was high in both sites with IDP camps and the residential site with no IDP camp. For all sites $\mathrm{HI}=38.40, \mathrm{CI}=11.40$ and $\mathrm{BI}=13.60$.

\section{Contribution to production of Aedes immature stages}

Contribution to productivity of Aedes larvae and pupae in all 4 sites with IDP camps (Omdoin, Ardamata, Elgabal and Almadaris) was higher in comparison with El shati residential area with no IDP camps. Despite this, public buildings in Ardamata and Elgabal sites reported higher PI values in comparison with public buildings in other study sites. Within the sites with IDPs camps both Omdoin and Ardamata reported higher PI (Table 2).

\section{Discussion}

The present study documents the presence of Ae. aegypti and Ae. vittatus mosquitoes during an outbreak of DF and chikungunya in El Geneina town. These species have been previously reported during the 1940 s and 1950s (9-11) and recently from different parts of Sudan including Port Sudan, Kassala and Elgadarief $(12,13)$. Ae. aegypti is a vector of several globally important arboviruses such dengue virus, YF virus and chikungunya virus (14-17). In Sudan, Ae. aegypti has been involved with outbreaks of YF in the Nuba Mountains and Darfur States, as well as DF and chikungunya in the Red Sea, Kassala and Elgadarief States $(12,13,18)$. Ae. vittatus plays an important role in transmitting several arboviral diseases such as YF, DF, chikungunya and zika virus disease (19-21). Therefore, further studies on the possible role of Ae. vittatus in transmitting arboviral diseases in El Geneina town are needed.

Six types of water containers were positive for Aedes immature stages in El Geneina town; tyres, zeers, barrels, plastic water tanks, flower vases and old cars. However, zeers might have been the main source of Aedes immature stages due to high numbers in comparison with other types of water containers. This can be explained by the habit of storing drinking water in zeers. Previous studies conducted in different regions in Sudan have revealed that storing drinking water in zeers and other types of water containers provides suitable breeding sites for $\mathrm{Ae}$. aegypti (12,13,22-24).

Many studies have highlighted the impact of climatic conditions on the abundance of Aedes mosquitoes (25-27). High abundance of Aedes mosquitoes during this study might also be linked to suitable temperature, humidity and rainfall during the rainy season, in addition to storing water for domestic usage. Other studies from neighbouring countries such as Saudi Arabia and other Asian countries have shown that the development of Ae. aegypti larvae and pupae in domestic containers occurs due to poor rain fall and water-storage practices (28-33).

In the present study high Stegomyia indices (HI, CI and BI) were reported from all sites including residential and public buildings. The high Stegomyia indices in public buildings could be attributed to presence of different types of water containers such as old cars and tyres in garages and large-volume barrels and plastic water containers in governmental organizations and guest houses, which hold water for a long time to fulfil the need of employees, vehicles and machines, as well as other general uses. Due to ignorance of proper covering and regular thorough cleaning of these water containers, they could be major source for Aedes immature stages. This could explain the high $\mathrm{HI}, \mathrm{CI}$ and $\mathrm{BI}$ in Elgabal.

The high Stegomyia indices in Elshati residential area in El Geneina town could be attributed to the high prevalence of tyres, which are a known source of Aedes mosquitoes, in addition to its close proximity to Wady 


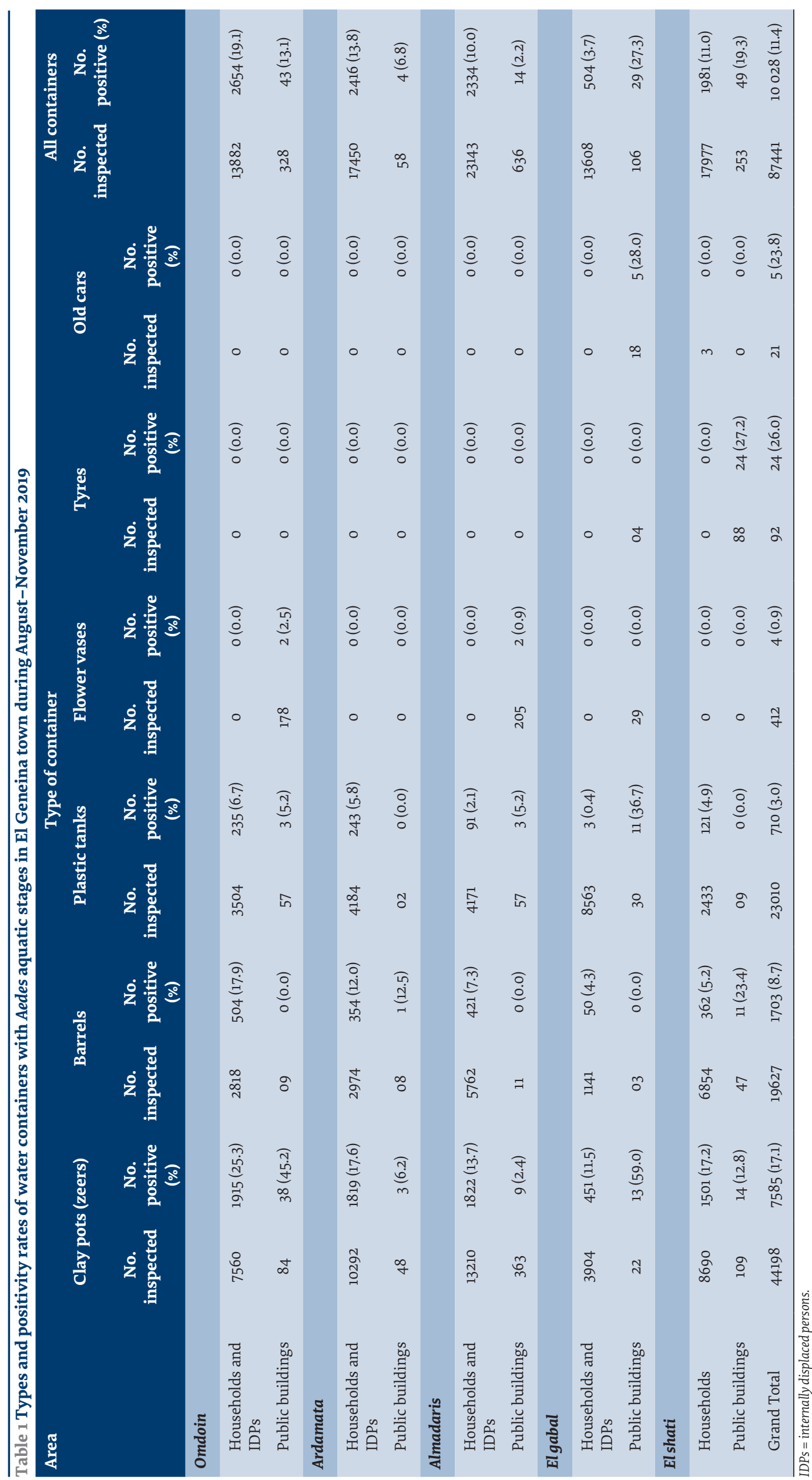




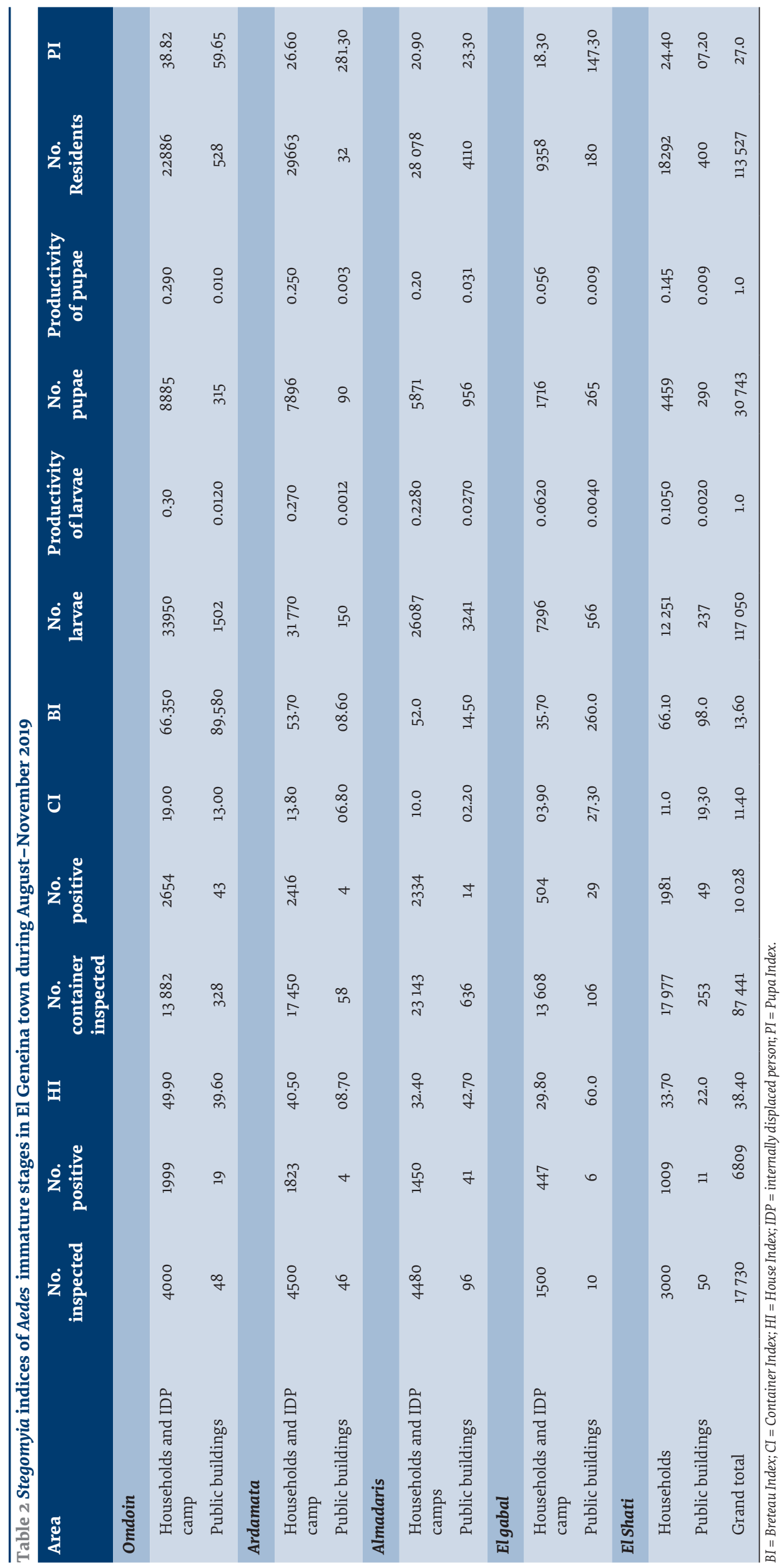


Kaja in the opposite direction to Omdoin. Wady Kaja banks contain numerous mango and guwafa trees, which are known habitats for Aedes aquatic stages.

Pupal index is the best indicator to estimate dengue virus transmission thresholds (34). The pupal index reported in this study during the rainy season was higher than that reported in Eastern Sudan (13), Kenya (35), Ethiopia (36) and Democratic Republic of Congo (37).

The intercommunal violence and instability of the area could complicate the epidemiological situation. Therefore, we consider these indices as alarming as the reported Stegomyia indices exceeded the previously mentioned parameter in other cities with DF, YF transmission inside and outside Sudan. In addition, the location of El Geneina town at the open border with Chad highlight the possibility of cross-border spread of DF, YF and chikungunya diseases.

\section{Conclusion}

A multisectoral response coupled with community participation are urgently needed to reduce the burden of Aedes-borne diseases in the unstable El Geneina town and to minimize the importation/exportation of communicable diseases through frequent cross-border population movement with Chad. Further studies should be carried out to study the possible role of Ae. vittatus in transmission of arboviruses in El Geneina town.

\section{Acknowledgement}

We would like to acknowledge Mr. Ahmed Mohammed Hamza World Health Organization El Geneina suboffice for his cooperation and Miss Rwnag Mohammed Adam, Hydraulics Research Centre, Ministry of Irrigation, Khartoum, Sudan.

Funding: The study was funded jointly by the Federal Ministry of Health and State Ministry of Health at Western Darfur.

Competing interests: None declared.

\section{Indices Stegomyia parmi les moustiques Aedes aux stades aquatiques dans la ville d'El-Genena dans l'ouest du Soudan}

\section{Résumé}

Contexte : Le Darfour, dans l'ouest du Soudan, compte les camps de personnes déplacées internes les plus instables et a connu plusieurs épidémies de dengue, de chikungunya et de fièvre jaune.

Objectifs : Déterminer la prévalence des moustiques Aedes aux stades aquatiques et les indices Stegomyia parmi ces derniers dans la ville d'El-Genena, au Darfour occidental.

Méthodes : Des enquêtes entomologiques transversales sur les stades immatures des moustiques Aedes ont été réalisées entre août et novembre 2019 dans quatre sites abritant des camps de personnes déplacées internes et dans une zone résidentielle sans camp.

Résultats : Nous avons recherché des larves d'Aedes dans 17730 maisons, camps de personnes déplacées internes et bâtiments de sociétés gouvernementales, et 6809 (38,4\%) étaient positifs pour les stades aquatiques du moustique Aedes. Des larves d'Aedes aegypti et d'Aedes vittatus ont été trouvées. Cependant, Ae. aegypti représentait plus de $90 \%$ des larves. Six récipients d'eau positive ont été recensés : pneus, pots en argile, barils, réservoirs d'eau en plastique, vases à fleurs et anciennes voitures : $26 \%$ des 92 pneus contenaient des larves d'Aedes contre 23,8\% des 21 anciennes voitures et 17,1 \% des 44198 pots en argile. Cela laisse penser que les pots en argile étaient la principale source d'Aedes. Les résultats ont révélé une infestation élevée de la ville d'El-Genena par des moustiques Aedes aux stades immatures dans tous les sites examinés, notamment les bâtiments publics et les zones résidentielles sans camps de personnes déplacées internes. Les indices Stegomyia variaient selon les sites d'étude ; ils étaient plus élevés dans les sites abritant des camps de personnes déplacées internes. Pour tous les sites, l'indice habitation était de 38,40, l'indice récipient de 11,40, l'indice de Breateu de 13,60 et l'indice pupaire de 27.

Conclusion : Une réponse multisectorielle et la participation de la communauté sont nécessaires de toute urgence pour réduire le fardeau des maladies transmises par les moustiques Aedes dans la ville d'El-Genena marquée par l'instabilité. 


\section{مؤشر ات السَّقفاوات لمر احل الزاعجة المائية في بلدة الجنينة، غرب السودان}

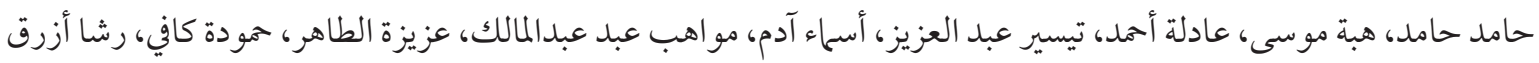

الخلفية: يضم إقليم دارفور غرب السودان أحد أكثر مخيمات النازحين داخليَّا تأثرًا، وقد شهدت هذه المخيمات العديد من فاشيات حمى الضنك و الشيكونجونيا و الخمى الصفر أفيماء.

الأهداف: هدفت هذه الدر اسة إلى تحديد معدل انتشار مؤشرات ”السَّقْفاوات“" مر احل ”الزاعجة“، المائية في بلدة الجنينة، غرب دارفور.

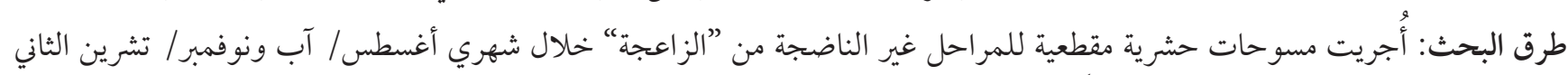

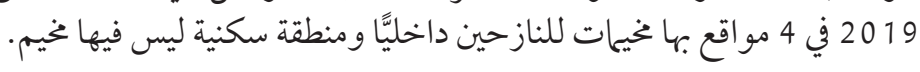

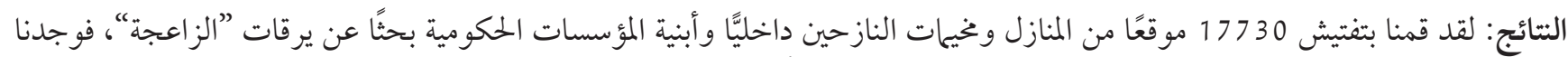

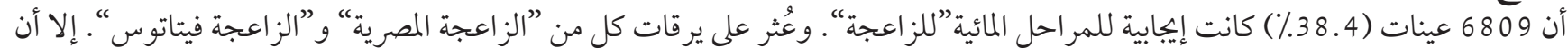

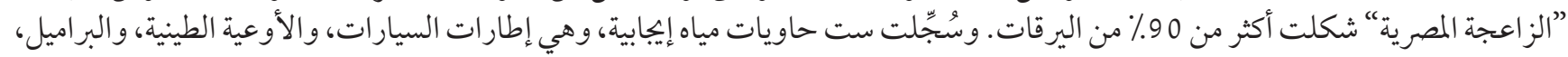

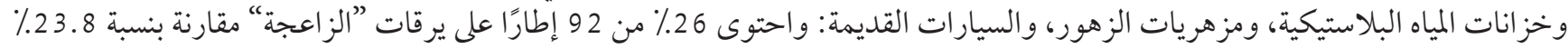

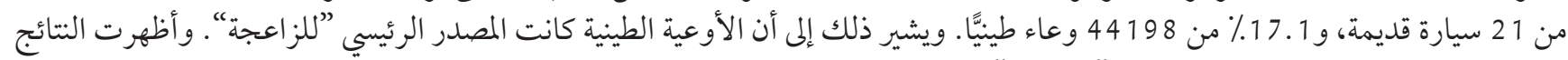

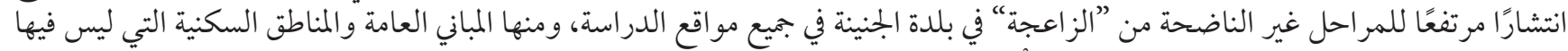

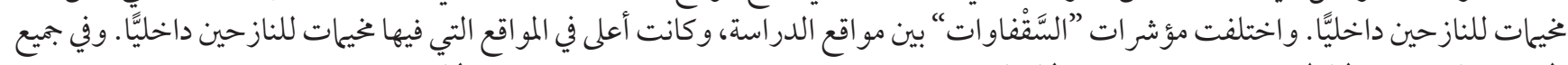

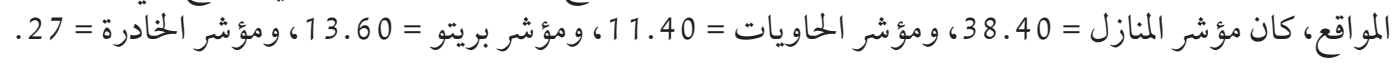

الاستناجات: توجد حاجة ماسة إلى استجابة متعددة القطاعات مقترنة بمشاركة بجتمعية من أجل تحفيف عبء الأمراض المبن المنقولة عن طريق

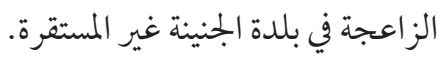

\section{References}

1. Ahmed A, Elduma A, Magboul B, Higazi T, Ali Y. The first outbreak of dengue fever in grater Darfur, Sudan. Trop Med Infect Dis. 2019 Mar 1;4(1):43. https://doi.org/10.3390/tropicalmed4010043 PMID:30823624

2. Soghaier MA, Hagar A, Abbas MA, Elmangory MM, Eltahir KM, Sall AA. Yellow fever outbreak in Darfur, Sudan in October 2012; the initial outbreak investigation report. J Infect Public Health. 2012 Oct;6(5):370-6. https://doi.org/10.1016/j.jiph.2013.04.007 PMID:23999341

3. Malaria and VHF outbreak in Sudan Situation Report No 09, covering the period 28 November to 4 December 2015. Federal Ministry of Health, World Health Organization (http://www.emro.who.int/images/stories/sudan/situation_report_no_09-_malaria_and_vhf_in_sudan_6_december_2015_1.pdf, accessed 9 November 2021).

4. Emergency preparedness and response/ chikungunya - Sudan 2018. World Health Organization; 2020 (www.who.int/csr/ don/15-october-2018-chikungunya-sudan/en/, accessed 9 November 2021).

5. Farnon EC, Gould LH, Griffith KS, Osman MS, Kholy AE, Brair M-E et al. Household-based sero-epidemiologic survey after a yellow fever epidemic, Sudan, 2005. Am J Trop Med Hyg. 2010 Jun;82(6):1146-52. https://doi.org/10.4269/ajtmh.2010.09-0105 PMID:20519615

6. Mohamed AH, Ali AM, Harbach RE, Reeves RG, Ibrahim KM, Mohmed MAA et al. Aedes mosquitoes in the Republic of the Sudan, with dichotomous keys for the adult and larval stages. J Natural Hist. 2017;51(9-10):513-29. https://doi.org/10.1080/o02229 33.2017.1285069

7. Operational guidelines for assessing the productivity of Aedes aegypti breeding sites. Geneva: World Health Organization; 2011 (https://www.who.int/tdr/publications/documents/sop-pupal-surveys.pdf, accessed 9 November 2021).

8. Dengue guidelines for diagnosis, treatment, prevention, and control. Geneva: World Health Organization; 2009 (https://apps. who.int/iris/handle/10665/44188, accessed 9 November 2021).

9. Lewis DJ. Observations on the distribution and taxonomy of Culicidae (Diptera) in the Sudan. Trans R Entomol Soc London. 1945 Jun;95(1):1-24. https://doi.org/10.1111/j.1365-2311.1945.tboo259.x

10. Edwards FW. Mosquitoes of the Ethiopian region. Vol. III, culicine adults and pupae. London: British Museum; 1941.

11. Mattingly PF, Knight KL. The mosquitoes of Arabia. I. Bull Br Museum Natural Hist), B Entomol. London: British Museum; 1956;4(3):89-141.

12. Abdalmagid MA, Alhusein ShH. Entomological investigation of Aedes aegypti in Kassala and Elgadarief States, Sudan. Sudan J Public Health. 2008;3(2):77-80.

13. Seid Ahmed OME, Siam HAM, Soghaier MA, Abubakr M, Osman HA et al. Dengue vector control and surveillance during a major outbreak in a coastal Red Sea area in Sudan. East Mediterr Health J. 2012 Dec;18(12):1217-24. https://apps.who.int/iris/handle/10665/118472 PMID:23301396 
14. Reinert JF, Harbach RE, Kitching IJ. Phylogeny and classification of tribe Aedini (Diptera: Culicidae). Zool J Linnean Soc. 2009;157:700-94. https://doi.org/10.1111/j.1096-3642.2009.00570.x

15. Jentes ES, Poumerol G, Gershman MD, Hill DR, Lemarchand J, Lewis RF et al. The revised global yellow fever risk map and recommendations for vaccination, 2010: consensus of the informal WHO Working Group on Geographic Risk for Yellow Fever. Lancet Infect Dis. 2011 Aug;11(8):622-32. https://doi.org/10.1016/S1473-3099(11)70147-5 PMID:21798462

16. Simmons CP, Farrar JJ, Chau VVC, Wills B. Dengue. N Engl J Med. 2012 Apr 12;366(15):1423-32. https://doi.org/10.1056/NEJMra1110265 PMID:22494122

17. Leparc-Goffart I, Nougairede A, Cassadou S, Prat C, de Lamballerie X. Chikungunya in the Americas. Lancet. 2014 Feb 8;383(9916):514. https://doi.org/10.1016/So140-6736(14)60185-9. https://doi.org/10.1016/So140-6736(14)60185-9

18. Yellow Fever Outbreak in Darfur, Sudan Situation Report No 6, 14 November 2012. Federal Ministry of Health, World Health Organization; 2012 https://reliefweb.int/report/sudan/yellow-fever-outbreak-darfur-sudan-situation-report-no-6-14-november-2012, accessed 9 November 2021).

19. Sudeep AB, Shil P. Aedes vittatus (Bigot) mosquito: an emerging threat to public health. J Vector Borne Dis. 2017 OctDec;54(4):295-300. https://doi.org/10.4103/0972-9062.225833 PMID:29460858

20. Jupp PG, McIntosh BM. Aedes furcifer and other mosquitoes as vectors of chikungunya virus at Mica, northeastern Transvaal, South Africa. J Am Mosq Control Assoc 1990 Sep;6(3):415-20. PMID:1977875

21. Diagne CT, Faye O, Guerbois M, Knight R, Diallo D, Faye O et al. Vector competence of Aedes aegypti and Aedes vittatus (Diptera: Culicidae) from Senegal and Cape Verde Archipelago for West African lineages of chikungunya virus. Am J Trop Med Hyg. 2014 Sep;91(3):635-41. https://doi.org/10.4269/ajtmh.13-0627 PMID:25002293

22. Eshag OSB, Bashir NHH, Dukeen MYH. Prevalence, habitat and productivity profiles of Aedes mosquitoes (Diptera: Culicidae) in Sennar state, Sudan. Int J Mosq Res. 2019;6(6):102-8.

23. Bakr AMA, Bashir NHH, Kehail MAA. Spatio-temporal distribution of Aedes mosquitoes (Diptera: Culicidae), in Alfasher locality north Darfur State, Sudan. Int J Mosq Res. 2018;5(5):127-30.

24. Ahmed RMH, Hassan SM. Seasonal indices of Aedes aegypti (Diptera: Culicidae) in an urban area of Kassala City, Sudan, 2014-2015. Eur Acad Res. 2019 Jan;VI(10):5933-48. https://euacademic.org/UploadArticle/3850.pdf

25. Johansson MA, Dominici F, Glass GE. Local and global effects of climate on dengue transmission in Puerto Rico. PLoS Negl Trop Dis. 2009;3(2):e382. https://doi.org/10.1371/journal.pntd.0000382 PMID:19221592

26. Al Ashry HA, Al Ghamdi AS, Al Shreef AZ, Kenawy MA. A preliminary study on the infestation indices of dengue vector, Aedes aegypti (Diptera: Culicidae) in Taif, Saudi Arabia. Int J Mosq Res. 2020;7(4):49-53.

27. Al-Ghamdi K, Khan MA, Mahyoub JA. Role of climatic factors in the seasonal abundance of Aedes aegypti L. and dengue fever cases in Jeddah province of Saudi Arabia. Curr World Environ. 2009;4(2):307-12. https://doi.org/10.12944/CWE.4.2.07

28. Bhat MA, Krishnamoorthy K. Entomological investigation, and distribution of Aedes mosquitoes in Tirunelveli, Tamil Nadu, India. Int J Curr Microbiol Appl Sci. 2014;3(10):253-60. https://www.ijcmas.com/vol-3-10/Mohd.\%20Ayoub\%20Bhat\%20and\%20K. Krishnamoorthy.pdf

29. Saleeza SNR, Saleeza Y, Rashid N, Sofian-Azirum M. Mosquitoes larval breeding habitat in urban and suburban areas, Peninsular Malaysia. Int J Bioeng Life Sci. 2011;5(10):599-603.

30. Wilson JJ, Sevarkodiyone SP, Karthikairaj K. Prevalence of mosquitoes in an agro-ecosystem (Athikulam, Virudhunagar district Tamilnadu, India). Acad J Entomol. 2013;6(2):61-5. https://www.idosi.org/aje/6(2)13/3.pdf

31. Sevarkodiyone SP. Spatial and temporal distribution of mosquitoes (Culicidae) in Virudhunagar district, Tamil Nadu, South India. Int J Mosq Res. 2014;1(3):4-9. https://www.dipterajournal.com/pdf/2014/volissue3/PartA/12.1a-345.pdf

32. Chareonviriyaphap T, Akratanakul P, Nettanomsak S, Huntamai S. Larval habitats and distribution patterns of Aedes aegypti (Linnaeus) and Aedes albopictus (Skuse), in Thailand. Southeast Asian J Trop Med Public Health. 2003 Sep;34(3):529-35. PMID:15115122

33. Sharma RS, Kaul SM,and Sokhay J. Seasonal fluctuations of dengue fever vector, Aedes aegypti (Diptera: Culicidae) in Delhi, India. Southeast Asian J Trop Med Public Health. 2005 Jan;36(1):186-90. PMID:15906665

34. Jimenez-Alejo A, Morales-Perez A, Nava-Aguilera E, Flores-Moreno M, Apreza-Aguilar S, Carranza-Alcaraz W et al. Pupal productivity in rainy and dry seasons: findings from the impact survey of a randomized controlled trial of dengue prevention in Guerrero, Mexico. BMC Public Health. 2017 May 30;(17 Suppl 1):428. https://doi.org/10.1186/s12889-017-4294-8 PMID:28699555

35. Agha SB, Tchouassi DP, Bastos ADS, Sang R. Assessment of risk of dengue and yellow fever virus transmission in three major Kenyan cities based on Stegomyia indices. PLoS Negl Trop Dis. 2017 Aug 17;11(8):e0005858. https://doi.org/o.1371/journal. pntd.0005858 PMID:28817563

36. Ferede G, Tiruneh M, Abate E, Kassa WJ, Wondimeneh Y, Damtie D, et al. Distribution and larval breeding habitats of Aedes mosquito species in residential areas of northwest Ethiopia. Epidemiol Health. 2018 Apr 23;40:e2018015. https://doi. org/10.4178/epih.e2018015. PMID:29748457

37. Wat'senga Tezzo F, Fasine S, Manzambi Zola E, Marquetti MDC, Binene Mbuka G, Ilombe G, et al. High Aedes spp. larval indices in Kinshasa, Democratic Republic of Congo. Parasit Vectors. 2021 Feb 1;14(1):92. https://doi.org/10.1186/s13071-021-04588-7.

PMID:33522947 